\title{
Correct or Incorrect Language: A Case of Iranian EFL Teachers
}

\author{
Giti Mousapour Negari \\ University of Sistan \& Baluchestan, Iran \\ Email: mousapour@hamoon.usb.ac.ir
}

\begin{abstract}
Research on teacher attitudes toward language and cultural differences has revealed that teachers form negative stereotypes of students with non-standard dialects (Münstermann, 1989). They consider dialect differences as deficiency in language learning, or sloppy pronunciation. Teacher's attitude toward the students is important in that it creates the classroom atmosphere and affects the way language is taught to the students. The immediate goal of the present study is to investigate EFL teachers' attitude toward dialect differences in Iran. It further investigates the roles that the variables like teachers' gender, teachers' years of teaching experience, school location and the students' ethnic background play in forming the teachers' attitude toward dialect variations. To this end, forty Iranian EFL teachers were randomly selected from nine different public high schools. To collect data, modified version of Hoover et al. (1996) Questionnaire was administered. The data were analyzed using simple frequency and percentages. The findings revealed that $\% 71$ of the teachers were sensitive toward varieties in dialect and considered them as forms of language and only \%14 viewed them as language learning deficiency. The study has some implications for language teaching and material development.
\end{abstract}

Index Terms - EFL teacher, teachers attitude, dialect variation, non-standard dialects

\section{INTRODUCTION}

Teachers' beliefs and attitudes are very important for understanding and improving educational affairs. These beliefs are closely related to the teachers' strategies for overcoming problems in their classroom settings. They form students' learning environment and influence student motivation and achievement. Dialects are varieties in language that represent cultural and regional differences among the speakers; however, to some teachers there is only one "correct" dialect-namely standard dialect-and many substandard and incorrect dialects. As far as dialects are viewed as social and personal qualities of different students, it seems necessary to investigate the teachers' attitudes toward different dialects in the classroom. Since the 60's, linguists have generally accepted that listeners form dialect-based judgments of speakers' intellectual ability and personal characteristics (Cross et al., 2001). A lot of research is necessary to explore whether teachers who are dealt with different dialects in the classroom are sensitive to students with non-standard dialects. Research has been done on speakers of dialects other than Standard English, such as African American English which have been concluded that it is a rule-governed dialect and not "sloppy speech" or "poor English". Negative attitudes toward dialects like African American English as Blake and Cutler (2003) stated are quite widespread as evidenced by researchers and educators. So it seems necessary to have an investigation on teachers' attitude toward dialect variations in a country like Iran with its diverse cultural and ethnical background. This paper tries to answer the following questions:

1. What is Iranian teachers' attitude toward dialect differences in Iran?

2. What variables may contribute to the attitudes?

\section{REVIEW OF LITERATURE}

Attitude as a concept is concerned with an individual way of thinking, acting and behaving. It has very serious implications for the learner, the teacher, the immediate social group with which the individual learner relates and the entire school system (Yara, 2009). The relationship between teachers' attitude and behavior and the students 'academic performance has been approved by a large body of research (Bowie \& Bond, 1994; Tauber, 1997). They provided the evidence that teachers' negative attitude and behavior is directly related to students' failure in learning a language. Sarwar (2002) in his research concluded that high academic achievers have better study habits and more positive study attitudes than low academic achievers. Snow, Burns, and Griffin (1998a) stated that children who speak nonstandard dialects of English may be at greater risk for reading difficulties. There is ample evidence that listeners make stereotyped judgments about speakers of particular dialects. Matthews (1980) for instance, found that the attitude of English teachers in Virginia tended to be more practical of substandard forms of language. Differences between the dialect children speak at home and the dialect taught at school may contribute to difficulties in learning to read. For example a teacher pointing out the "d" sound in the words "sold" or "find" can confuse the African American child who pronounces these words "sol" and "fine." A student who pronounces the words "deaf" and "death" in the same way is 
likely to be confused if the teacher uses these words in a lesson on contrasting final consonants. However, these kinds of confusions in phonemic awareness and reading instruction can largely be avoided by making teachers more aware of dialect difference (Burns et al., 1999).

Teachers' characteristics such as attitude and years of teaching experience have been studied to explore their effects on students' academic achievement (Wright, Horn \& Sanders, 1997). Further investigation was done by Wenglinsky (2000). In his study he concluded that teachers with a major or minor in the subject area of their teaching will provide greater gains in student achievement in both mathematics and science. He further claimed that this remained true even after controlling for teacher professional development, teacher classroom practices, class size, and student demographics. Hawkins, Stancavage, and Dossey (1998) stated that even though teaching experience seems to be related to student achievement, the relationship may not be linear; students whose teachers had fewer than 5 years of experience had lower levels of mathematics achievement, but there were no differences in mathematics achievement among students whose teachers had more than 5 years of experience. Other researchers, on the other hand, found different results. Hanushek (1997) found that 71 percent of the studies he surveyed did not explore any findings to support a relationship between teachers' teaching experience and student achievement.

Labov and Hudley (2009) emphasized on two main factors associated with dialect that may affect students' academic achievement: (1) structural differences, phonemic inventory and grammatical rules that may interfere with reading and learning in standard English; and (2) symbolic influences, the social and psychological factors that result from the perceptions of teachers and others about the abilities and conduct of students who speak certain dialects. With this respect teachers may view some dialects as weaker intellectual ability or low educational aspirations, and this may cause students to lower their own academic expectations (Adger, Wolfram \& Christian, 2007). The effect may be even more than just lowering their expectations. According to Delpit (2006) children and youth who are criticized and corrected for speaking in their own dialect may develop oppositional attitudes towards school. Eades(1995) maintained that students who speak Standard English as a second dialect show poor Standard English language skills, and although factors other than dialect may be involved, several studies suggest that the failure to specifically address dialect diversity may be contributing to their underachievement.

\section{Methodology}

\section{A. Participants}

Forty Iranian EFL teachers were selected from nine different high schools (located in different regions of the city) in Zahedan and were asked to complete the questionnaire. Zahedan by nature is a city in which a variety of people from the other cities with different ethnic backgrounds live. The respondents varied in age, gender, number of years teaching, classes taught, as well as ethnicity of the students they taught.

\section{B. Instruments}

The modified version of the questionnaire by Hoover et al. (1996) was used to collect the data. The first part included the participants' age, sex, ethnicity, educational background and teaching experience. The second part of the questionnaire consisted of statements designed to assess teachers' attitudes toward different topics. The first section measures whether respondents recognize variation in people's speech, its influence on school performance, and on their feelings about education. The second set of statements measure attitudes toward differences in dialect in general. Respondents are then asked to evaluate the appropriateness of different dialects in and outside the classroom. Finally, respondents are asked to evaluate whether standard dialect is dominant because it is the best form of language, and whether it is the role of the school to make certain that all students have the same chances to succeed. A Lickert-type scale was used to evaluate statements from "agree strongly" to "disagree strongly." In other words, the respondents are given the following choices in ranking their feelings toward statements: (a) agree strongly, (b) agree mildly, (c) no opinion, (d) disagree mildly, (e) disagree strongly. The reliability of the scale measured from 0.89 to 0.93 (AbdulHakim, 2002).

\section{Procedure}

The questionnaire was distributed to teachers at the nine selected schools, in which the students were from different ethnic backgrounds. Teachers generally received the questionnaire at the break time and were asked to return them anonymously. The participants were also asked to add any comments. Many of them provided us with useful comments. Several remarked that it is better to refer to Standard dialect in the questionnaire as the "correct" form of language rather than the "best" form of language. Some others proposed that dialect speakers be placed in classes alongside ELL students. The data gathered through the analysis of the questionnaires may suggest that there may be a correlation between teachers' attitudes and students learning success.

\section{DATA ANALYSIS AND RESUlts}

As it is represented in Table 1, regarding the gender of the participants there were 10 males, 27 females and 3 for those who didn't respond to the age item. 
TABLE1:

SEX OF THE RESPONDANTS

\begin{tabular}{|l|l|}
\hline Sex of the respondents & N \\
\hline Male & 10 \\
Female & 27 \\
No response & 3 \\
\hline
\end{tabular}

Table 2 represents the respondents' years of teaching experience. As it is shown most of the respondents had an experience of more than 10 years.

TABLE2:

YEARS OF TEACHING EXPERIENCE

\begin{tabular}{|l|l|}
\hline Years of teaching experience & $\mathrm{N}$ \\
\hline 0-1 years & 6 \\
3-5 years & 9 \\
6-10 years & 7 \\
10 years or more & 18 \\
\hline
\end{tabular}

Table 3 demonstrates different ethnic groups of students who were taught by the teachers in different high schools.

TABLE3:

ETHNIC GROUP OF STUDENTS TAUGHT

\begin{tabular}{|l|l|}
\hline Ethnic group of students taught & N \\
\hline Sistani & 79 \\
Borujerdi & 68 \\
Mashhadi & 33 \\
\hline
\end{tabular}

While the data set for this study is not large, the results do suggest noteworthy and significant results. Following are the results for the attitudinal part of the survey. They are discussed for the aforementioned social categories in terms of percentages and favorability toward statements.

\section{A. By School}

Fig. 1 shows that in all nine schools, the respondents almost categorically acknowledge (95\%) variation in language and agree $(90 \%)$ that students who do not speak Standard Persian may suffer academically (Survey questions 1, 2, and $5)$.

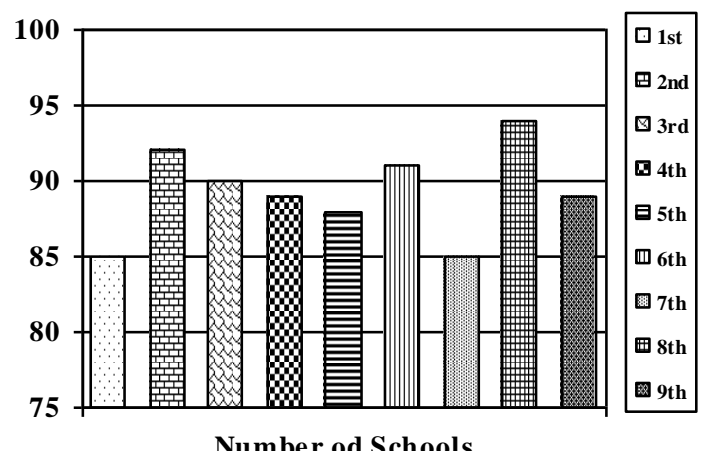

Figure1. Bilingual Education is the right of every child who does not speak the dominant language.

\section{B. By Sex of the Respondents}

In this study, the results for the men and women are comparable for all statements. In fact, there is an average of only 3-7 percentage points' difference for any statement.

\section{By Years Taught in the School System}

The majority of the teachers in our sample have been teaching for 10 or more years. This group comprises a large percentage (\%45) of our sample, and the remaining 55 percent of the informants are divided among the four remaining factor groups. Nonetheless, we find little variation in the frequencies for responses between the various groups at this time.

\section{By Students' Ethnicity}

As Fig. 2 shows the teachers are generally more likely to support bidialectical (the ability of individuals to control two distinct dialects of the same language) education and they agree that such students have problems similar to ESL 
students. It was further discovered that the same teachers feel that standard dialect is dominant in the society and it is the best form of Persian.

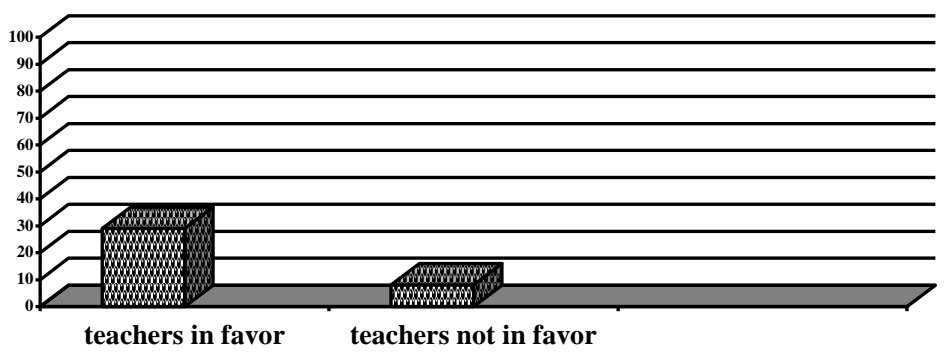

Figure2. Bidialectal education is the right of every child who does not speak the dominant language or dialect.

\section{DISCUSSION}

As the analysis of the data reveals the teachers in the nine high schools appear to have an understanding of language variation and dialects. A substantial (71\%) percentage view dialects as forms of language with only 14 percent viewing it as lazy forms of Persian. In addition, 53 percent of teachers responded that dialects have its own set of rules. Only 22 percent agree that Standard Persian is the best form of Persian language.

The results revealed the importance of language diversity in educational settings and the need for positive attitudes toward the issues of dialect difference. Teachers' attitude towards the teaching of language plays a significant role in shaping the attitude of students towards the learning of language. The teachers have to keep these differences in their mind and help the students maintain their confidence even though they have non-standard dialects. The teachers are recommended to implement an approach to teaching students that encourages respect for language diversity and ask them to cooperate with each other. In terms of pedagogy, a high percentage of the teachers (86\%) believe that students with nonstandard dialects have problems similar to students learning a second/foreign language. As Fig. 2 above demonstrates majority of teachers agreed upon this fact that essential care should be given to the issue of bidialectisim. The students who do not speak the standard dialect may face problems very similar to second or foreign language learners. Similarly, most of the teachers feel that it is educationally acceptable to use the students' first language to teach the standard language. The fact that students are allowed to maintain their native language in the classroom provides an environment that encourages and welcomes dialect diversity. A small number of the teachers responded that Standard Persian is dominant in school and business as it is the best form of Persian.

In sum, in terms of bilingual and bidialectal education, nearly half (55\%) of the teachers in the study supported bilingual education, and a great proportion (62\%) supported to plan these types of programs. The study furthermore showed that teachers' attitudes play a main role in the experiences of students, and predictions of students' academic achievement are related to assessment of their speech. Half of the teachers agree that students with dialect diversity need to have special education very similar to the students who learn a second or foreign language, but minority (20\%) of them preferred to use the students' first language as a medium to teach Standard Persian.

\section{CONCLUSION AND PEDAGOGiCAl IMPLiCATIONS}

This study was developed to investigate Iranian EFL teachers' attitude toward dialect differences to add to the findings of the existing research. The study shed light on how to deal with the varieties of standard languages and that to know the problems (educationally, socially, or psychologically) which students with non-standard language may face in the classroom. The findings revealed that 71percent of the teachers were sensitive toward varieties in dialect and considered them as forms of language and only 14 percent viewed them as language learning deficiency. Based on the results of the study which focus on the students' dialect diversities, a need to teacher training program is felt. The teachers should be aware of the needs of the students who are nonstandard speakers. As Smitherman (1999) stated there are two points to be regarded with respect to language varieties. One is that we need to have a policy specialized for language diversities, and the other one is that as far as language attitudes are concerned, the schools are the place for social change. What is new in this research is that language programmers and curriculum developers should take into account attitudes held by the teachers in the classrooms and that linguistic background of the students may act as a medium for acquiring standard language.

Very little effort has been done in educational settings to restructure educational policies for students with nonstandard dialects. In other words, we need language policies that assure the students that they do not fail due to not being a speaker of Standard Persian. Enormous efforts are required from linguists and other social scientists to help to improve public attitudes (Blake, 2000). The study suggests that teachers' attitudes to dialect differences have natural consequences for the students, so it demands enough care and sensitivity from the teachers as well as from the students' 
parts. Charity et al. (2004) referred to this sensitivity as "dialect awareness" and maintained that children's awareness of dialect differences in their speech community may increase their ability to think about and manipulate language. Being aware of these variations may help the students experience less interference from dialect mismatches and therefore experience less difficulty in language learning. Some approaches had been proposed for embedding first dialects in so called bidialectal education (Harris-Wright, 1999, in Dekalb County, Georgia, and through the Kamahameha Schools in Hawaii (Baugh, 2007)). These approaches have been classified by Rickford (2003, cited in Alim, 2005, p.27) into: a) the linguistically informed approach through which teachers learn to distinguish between errors deriving from first dialect interference and those from language development; b) the dialect reader approach in which the materials developed in the home dialect are used to bridge between the first and second dialect, and c) the dialect awareness approach where students learn the inherent variability of language.

The study has some implications for material designers, too. According to Snow et al. (1998b) a teacher who is sufficiently knowledgeable and sensitive about dialect differences will prepare materials and lessons that are consistent with the phonology, syntax, and vocabulary of the children's dialect. With this respect syllabus designers and material developers should design programs that consider the variables which can promote teacher's motivation and teacher's interest. By so doing, they will be able to play their roles efficiently in educational settings. Garman (2004) suggests four factors practical in bringing about positive attitude change: i) exposure to different cultures, ii) education, iii) travel, and iv) personal experience of discrimination. The other important implication of this study is that teacher training centers are needed to give the teachers more background and understanding appropriate to their preferred teaching methods and strategies that they can use in the classrooms with varied dialects. Meanwhile, there should be a set of specific guidelines for the teachers to have the opportunity to restructure old beliefs about the superiority of the standard dialect.

\section{APPENDIX}

(The items taken and adapted from the questionnaire developed by Hoover et al., 1996)

1. People speak differently in different situations.

Agree Strongly Agree Mildly No Opinion Disagree Mildly Disagree Strongly

2. In every language there are always variations in the way people from different age, class and academic backgrounds speak.

Agree Strongly Agree Mildly No Opinion Disagree Mildly Disagree Strongly

3. Bilingual education is the right of every child who does not speak the dominant language.

Agree Strongly Agree Mildly No Opinion Disagree Mildly Disagree Strongly

4. Government funds should be used to support bilingual education.

Agree Strongly Agree Mildly No Opinion Disagree Mildly Disagree Strongly

5. Some children do poorly in school because they do not speak Standard Persian. Agree Strongly Agree Mildly No Opinion Disagree Mildly Disagree Strongly

6. Bidialectal education is the right of every child who does not speak the dominant language or dialect.

Agree Strongly Agree Mildly No Opinion Disagree Mildly Disagree Strongly

7. Government funds should be used to support Bidialectal education.

Agree Strongly Agree Mildly No Opinion Disagree Mildly Disagree Strongly

8. Different dialects are forms of Persian.

Agree Strongly Agree Mildly No Opinion Disagree Mildly Disagree Strongly

9. Dialects are lazy Persian.

Agree Strongly Agree Mildly No Opinion Disagree Mildly Disagree Strongly

10. Dialects are subject to their own set of rules.

Agree Strongly Agree Mildly No Opinion Disagree Mildly Disagree Strongly

11. Kids with nonstandard dialect would advance further in school without Standard Persian. Agree Strongly Agree Mildly No Opinion Disagree Mildly Disagree Strongly

12. Using dialects as a tool to teach subjects to students would hurt their chances to learn Standard Persian. Agree Strongly Agree Mildly No Opinion Disagree Mildly Disagree Strongly

13. There are settings outside the classroom where dialects are appropriate. Agree Strongly Agree Mildly No Opinion Disagree Mildly Disagree Strongly

14. It is educationally sound to use a student's first language as a way of teaching that student the standard language of a community.

Agree Strongly Agree Mildly No Opinion Disagree Mildly Disagree Strongly

15. Different dialects are inadequate for teaching subjects such as social studies or math. Agree Strongly Agree Mildly No Opinion Disagree Mildly Disagree Strongly

16. Students with nonstandard dialects have problems similar to those of students learning Persian as a second language.

Agree Strongly Agree Mildly No Opinion Disagree Mildly Disagree Strongly

17. Students with nonstandard dialects should be taught in classrooms alongside Persian as a second language. 
Agree Strongly Agree Mildly No Opinion Disagree Mildly Disagree Strongly

18. Standard Persian is dominant in schools and business because it is the best form of English. Agree Strongly Agree Mildly No Opinion Disagree Mildly Disagree Strongly

19. One purpose of school is to make certain that all students graduate proficient in Standard Persian. Agree Strongly Agree Mildly No Opinion Disagree Mildly Disagree Strongly

\section{REFERENCES}

[1] Adger, C. T., Wolfram, W., \& Christian, D. (2007). Dialects in schools and communities. Mahwah, NJ: Lawrence Erlbaum.

[2] Alim, S. H. (2005). Critical language awareness in the United States: Revisiting issues and revising pedagogies in a resegregated society. Educational Researcher, 34, 24-31.

[3] Ball, J., Bernhart, B., \& Deby, J. (2006). First Nations English Dialects: Exploratory project proceedings. Unpublished monograph, University of Victoria and University of British Columbia.

[4] Baugh, J. (2007). Plantation English in America: Nonstandard varieties and the quest for educational equity. Research in the Teaching of English, 41(4), 465-472.

[5] Blake, R. (2000). Review of Making the connection: Language and academic achievement among African American students. C. T. Adger, D. Christian, \& O. Taylor (Eds.). Journal of Sociolinguistics 4(1), 132-135.

[6] Blake,R. and Cutler, C. (2003). AAE and variation in teachers' attitudes: A question of school philosophy? Linguistics and Education, 14 (2), 163-194.

[7] Bowie, R. L, and C. L. Bond. (1994). Influencing teachers' attitudes towards Black English: Are we making a difference? Journal of Teacher Education 45, 112-118.

[8] Burns, M. S., Griffin, P., \& Snow, C. E. (1999). Starting out right. A guide to promoting children's reading success. Washington, DC: National Academy Press.

[9] Charity, A. H., Scarborough, H. S., \& griffin, D. M. (2004). familiarity with school English in African-American children and its relation to early reading achievement. Child Development, 75, 1340-1356.

[10] Cross, B.John., DeVaney, Thomas., and Jones, Gerald.(2001). Pre-Service Teacher Attitudes Toward Differing Dialects. Linguistics and Education. 12(2), 211-227

[11] Delpit, L. (2006). Other people's children: Cultural conflict in the classroom. New York: The New Press.

[12] Eades, D. (1995). Aboriginal English. North Sydney, Australia: Board of Studies, NSW.

[13] Garman, M. (2004). Changing preservice teachers' attitudes/beliefs about diversity: What are the critical factors? Journal of Teacher Education, 55(3), 201-213.

[14] Hanushek, E.A. (1989). The impact of differential expenditures on school performance. Educational Researcher, 18(4), 45-65

[15] Harris-Wright, K. (1999). Enhancing bidialectalism in urban African American students. In C. T. Adger, D. Christian \& O. Taylor (Eds.), Making the connection: Language and academic achievement among African American students (pp. 53-59): Urbana, IL: National Council of Teachers.

[16] Hawkins, E.F., Stancavage, F.B., \& Dossey, J.A. (1998). School policies and practices affecting instruction in mathematics. (NCES 98495). Washington, DC: U.S. Department of Education, National Center for Education Statistics.

[17] Hoover, M. R., McNair-Knox, F., Lewis, S. A. R., \& Politzer, R. L. (1996). African American English attitude measures for teachers. In R. L. Jones (Ed.), Handbook of tests and measurements for Black populations (Vol. 1, pp. 83-93). Hampton, Virginia: Cobb \& Henry Publishers.

[18] Labov, W., and Hudley, A.C. (2009). Symbolic and Structural Effects of Dialects and Immigrant Minority Languages in Explaining Achievement Gaps. Paper prepared for the Workshop on the Role of Language in School Learning: Implications for Closing the Achievement Gap, October 15-16, Hewlett Foundation, Menlo Park, CA. Available: http://www7.nationalacademies.org/cfe/Paper_Labov_and_Hudley.pdf [accessed June 2012].

[19] Matthews, H (1980). Attitudes and classroom behaviors of Virginia middle school English teachers regarding Black English and certain other usages. Dissertation Abstracts International 41, 3861-3862.

[20] Münstermann, H. (1989). Language attitudes in education. In J. Cheshire, V. Edwards, H. Münstermann \& B. Weltens (Eds.), Dialect and Education (pp. 166-181). Clevedon, England: Multilingual Matters Ltd.

[21] Sarwar, M. (2002). A Comparison of study Habits and Attitudes of Low and High Achievers at Secondary Level. Unpublished Thesis University of. A.I.O. Islamabad.

[22] Smitherman, G. (1999). Language policy and classroom practices. In C. T. Adger, D. Christian, \& O. Taylor (Eds.), Making the connection: Language and academic achievement among African American students (pp. 115-124). McHenry, IL: Delta Systems and Washington, D.C.: Center for Applied Linguistics.

[23] Snow. Catherine, Burns. Susan and Peg Griffin. (1998 a). Dialect and Reading Difficulties. Retrieved May 3, 2012 from http://www.readingrockets.org/article/290

[24] Snow, C. E., Burns, S. M., \& Griffin, P. Editors. (1998 b). Preventing Reading Difficulties in Young Children. Committee on the Prevention of Reading Difficulties in Young Children. National Research Council, National Academy Press.

[25] Tauber, R. T. (1997). Self-Fulfilling prophecy: A practical guide to its use in education. West Port, CT: Praeger.

[26] Wenglinsky, H. (2000). Teaching the teachers: Different settings, different results. Princeton, NJ: Educational Testing Service.

[27] Wright, S. P., Horn, S. P. \& Sanders, W. L. (1997). Teacher and classroom context effects on student achievement: Implications for teacher evaluation. Journal of Personnel Evaluation in Education, 11, 57-67

[28] Yara, P.O. (2009). Relationship between Teachers' Attitude and Students' Academic Achievement in Mathematics in Some Selected Senior Secondary Schools in Southwestern Nigeria. European Journal of Social Sciences, 1 (3), 364-369

Giti Mousapour Negari is an Assistant Professor of Applied Linguistics in University of Sistan \& Baluchestan. 
She received her BA in English Language teaching, University of Sistan \& Baluchestan in 1992. She then got her MA in TEFL from Tehran University in 1996. She received her doctoral degree in TEFL from Isfahan University, Iran, in 2006.

She has published in Iranian as well as International professional journals in different fields such as psycholinguistics, English language skills, English Teaching methods, strategy instruction and lexical acquisition. Dr Mousapour has presented papers in International conferences such as CamTESOL Conference on English Language Teaching 2012, TESOL Asia \& Asian EFL Journal International TESOL Conference 2011. In addition, she has authored books in related fields. 